\title{
Matriks Leslie dan Aplikasinya dalam Memprediksi Jumlah dan Laju pertumbuhan Penduduk di Kota Makassar
}

\author{
Wahidah Sanusi ${ }^{1}$, Sukarna ${ }^{1}$, dan Nur Ridiawati ${ }^{1}$, a) \\ ${ }^{1}$ Jurusan Matematika, Fakultas Matematika dan Ilmu Pengetahuan Alam \\ Universitas Negeri Makassar \\ a) nurridiawatiipa1@ymail.com
}

\begin{abstract}
Abstrak. Pertumbuhan penduduk merupakan suatu hal yang perlu diperhatikan, sebab jika pertumbuhan penduduk tidak terkontrol maka akan sulit bagi pemerintah untuk melakukan pensejahtraan. Di kota Makassar sendiri pada tahun 2010 tercatat 1.339.374 jiwa dengan laju pertumbuhan sebesar 1,65 persen per tahunnya. Penelitian ini bertujuan untuk memprediksi laju dan pertumbuhan penduduk di kota Makassar pada tahun 2017 dengan menggunakan Matriks Leslie. Adapun faktor yang berpengaruh dalam pertumbuhan penduduk adalah tingkat kesuburan, tingkat ketahanan hidup, dan rentang umur dari penduduk. Langkah-langkah yang dilakukan untuk memprediksi jumlah penduduk $p$ tahun berikutnya dengan menggunakan Matriks Leslie adalah membentuk sebuah vektor kolom $n(t)$ yang entrinya merupakan jumlah awal penduduk tiap kelas umur. Kedua dicari $n(t+p)$ yang merupakan jumlah penduduk untuk $p$ tahun berikutnya menggunakan rumus $n(t+p)=A^{p} n(t)$ dengan A merupakan Matriks leslie dan terakhir dicari nilai eigen dominan. Hasil prediksi pada tahun 2017 diperoleh sebanyak 749.090 jiwa dengan nilai eigen $\lambda_{1}=1.01$ yang menunjukkan pertumbuhan cenderung meningkat.
\end{abstract}

Kata Kunci : Matriks Leslie, Pertumbuhan Penduduk, Nilai Eigen

\begin{abstract}
Population growth is a matter of note, if the population growth is not controlled, it will be difficult for the government to make prosperity. In 2010, In the city of Makassar was recorded 1,339,374 people with a growth rate of 1.65 percent every year. This study aims to predict the number and rate of population growth in Makassar city in 2017 by using Leslie Matrix. The factors which influence the population growth are the fertilit rate, the survival rate, and the age range of the population. The steps taken to predict the number of population $p$ for the next year with using Leslie Matrix are forming a vector column $n(t)$ whose entry is the initial number of population every age class. The second step is obtain the value of $n(t+p)$ which is the population number for the next year $p$ than use the formula $n(t+P)=A^{p} n(t)$ with $A$ is the Leslie Matrix. And the last step, specify the dominant eigen value. The results obtained in 2017 predicted a total of 749,090 inhabitants with eigen values $\lambda_{1}=1.01$ indicates that growth tends to raise.
\end{abstract}

Keywords: Leslie Matrix, Population Growth, Eigen Values

\section{PENDAHULUAN}

Penduduk merupakan aset penting dari suatu wilayah, namun perlu diperhatikan, pertumbuhan penduduk yang tidak terkontrol justru akan menjadi permasalahan, bukan tidak mungkin jika angka kelahiran di suatu wilayah semakin meningkat maka pemerintahpun akan semakin sulit untuk mensejahterakan penduduk di wilayah tersebut. 
Pertumbuhan penduduk yang terjadi di Kota Makassar saat ini selalu mengalami peningkatan. Badan Koordinasi dan Keluarga Berencana (BKKBN) Makassar mencatat laju pertumbuhan penduduk di Kota Makassar selalu meningkat, peningkatan pertumbuhan penduduk berdasarkan sensus penduduk tahun 2010 terdapat 1.339 .374 jiwa dengan laju pertumbuhan penduduk ratarata sebesar 1,65 persen per tahunnya (Daniel, 2014). Penekanan harus selalu ditingkatkan guna menjaga kualitas sumber daya manusia di Kota Makassar.

Matematika dengan disiplin ilmunya menawarkan solusi untuk memprediksi jumlah dan laju pertumbuhan suatu penduduk pada tahun berikutnya dengan menggunakan Matriks Leslie. Kenyataan membuktikan bahwa untuk menyelesaikan masalah-masalah dalam kehidupan seharihari, matematika mempunyai peranan yang sangat penting (Yuliani, 2012).

Dalam Buletin ilmiahnya, Pratama dkk (2013) mengatakan bahwa Matriks Leslie adalah sebuah matrik yang memiliki bentuk unik berbentuk matriks persegi dimana entri dari baris pertama terdiri dari tingkat kesuburan penduduk, sub diagonalnya berisi tingkat ketahanan hidup penduduk dan entri yang lain bernilai nol. Matriks Leslie ditemukan oleh seorang pakar Ekologi bernama Leslie pada tahun 1945 (Anton Rorres, 2004).

Pertumbuhan penduduk dapat dikatakan sebagai perubahan jumlah pada suatu penduduk yang dipengaruhi oleh keadaan internal dari penduduk tersebut, meliputi kelahiran, kematian, dan ketahanan hidup (Pratama dkk, 2013). Pertumbuhan penduduk dapat memberikan informasi apakah perubahan jumlah penduduk pada tahun berikutnya selalu meningkat, menurun atau tetap.

Sehingga digunakanlah Matriks Leslie sebagai model pertumbuhan penduduk untuk mengetahui prediksi jumlah dan prediksi laju pertumbuhan dari suatu penduduk pada tahun berikutnya. Faktor-faktor yang digunakan pada perhitungan dengan Matriks Leslie adalah kelas umur dari suatu penduduk, faktor tingkat kesuburan penduduk, dan tingkat ketahanan hidup penduduk.

\section{Matriks}

Definisi 2.1 (Munir, 2010:98)

Matriks adalah susunan skalar elemen-elemen dalam bentuk baris dan kolom. Matriks A yang berukuran dari $\mathrm{m}$ baris dan $\mathrm{n}$ kolom $(\mathrm{m} \times \mathrm{n})$ adalah:

$$
A=\left[\begin{array}{lllll}
a_{11} & a_{12} & a_{13} & \mathrm{~K} & a_{1 n} \\
a_{21} & a_{22} & a_{23} & \mathrm{~L} & a_{2 n} \\
\mathrm{M} & \mathrm{M} & \mathrm{M} & \mathrm{L} & \mathrm{M} \\
a_{m 2} & a_{m 2} & a_{m 3} & \mathrm{~L} & a_{m n}
\end{array}\right]
$$

Entri $a_{i j}$ disebut elemen matriks pada baris ke- $i$ dan kolom ke-j. Jika m=n maka matriks tersebut dinamakan juga matriks bujur sangkar (Munir, 2010:98).

\section{Matriks Kolom dan Baris}

Ukuran suatu matriks dinyatakan dalam bentuk baris dan kolom. Suatu matriks yang terdiri dari satu kolom disebut matriks kolom. Suatu matriks yang hanya terdiri dari satu baris disebut matriks baris (Anton dan Rorres, 2004:26).

$$
B=\left[\begin{array}{c}
a_{11} \\
a_{21} \\
\mathrm{M} \\
a_{m 2}
\end{array}\right], \quad C=\left[\begin{array}{lllll}
a_{11} & a_{12} & a_{13} & \mathrm{~K} & a_{1 n}
\end{array}\right]
$$

Matriks $B$ adalah matriks kolom. Sedangkan matriks $C$ adalah matriks baris. 


\section{Matriks Bujur Sangkar}

Matriks Bujur Sangkar ialah matriks yang jumlah baris sama dengan jumlah kolom atau berukuran $\mathrm{n} \times \mathrm{n}$. Pada matriks bujur sangkar dikenal istilah elemen diagonal, yang terletak pada entri $a_{11}, a_{22}, a_{33}$ dan seterusnya (Aini dan Utami, 2013:22).

$$
\mathrm{D}=\left[\begin{array}{lll}
a_{11} & a_{12} & a_{13} \\
a_{21} & a_{22} & a_{23} \\
a_{31} & a_{32} & a_{33}
\end{array}\right]
$$

\section{Perkalian Matriks dengan Skalar}

Jika $A$ adalah suatu matriks sebarang dan $c$ adalah skalar sebarang, maka hasil kali $c A$ adalah matriks yang diperoleh dari perkalian setiap entri pada matriks $A$ dengan bilangan $c$. Matriks $c A$ disebut sebagai kelipatan skalar (scalar multiple) dari A (Anton dan Rorres, 2004: 29).

\section{Perkalian antar Matriks}

Dua buah matriks hanya dapat dikalikan apabila jumlah kolom dari matriks yang dikalikan sama dengan jumlah baris dari matriks pengalinya. Jika $A$ adalah matriks $m \times r$ dan $B$ adalah matriks $r$ $\times n$, maka hasil kali $A B$ adalah matriks $\mathrm{m} \times \mathrm{n}$ yang elemen-elemennya ditentukan sebagai berikut.

Untuk mencari elemen dalam baris $i$ dan kolom $j$ dari $A B$, pilih baris $i$ dari matriks $A$ dan kolom $j$ dari matriks $B$. Kalikan elemen-elemen yang bersesuaian dari baris dan kolom tersebut bersamasama dan kemudian tambahkan hasil kali yang dihasilkan (Anton dan Rorres, 2004: 30).

\section{Perkalian Matriks Bujur Sangkar dan Matriks Kolom}

Dalam buku Aljabar Linear Dasar, Aini dan Utami (2013) mengatakan bahwa untuk mendefinisikan hasil kali matrik A yang berukuran $m \times r$ dengan matriks $B$ yang berukuran $m \times m$ yang merupakan perkalian matriks baris dengan matriks bujur sangkar caranya ialah ukuran kolom matriks A yang sama dengan baris matriks B dihilangkan, sehingga hanya ukuran baris matriks A dan kolom matriks B, hasilnya adalah matriks baris baru.

Dengan mengikuti aturan perkalian matriks baris dengan matriks bujursangkar maka sebuah matriks kolom juga dapat dikalikan dengan sebuah matriks bujur sangkar, dengan catatan jumlah kolom matriks kolom sama dengan jumlah baris matriks bujursangkar, hasilnya adalah matriks kolom baru.

\section{Determinan}

Definisi 2.2 (Aini dan Utami, 2013:55)

Determinan adalah fungsi khusus yang mengasosiasikan suatu bilangan real dengan suatu matriks bujur sangkar.

Fungsi determinan matriks bujursangkar A sering dituliskan sebagai jumlah semua hasil kali elementer bertanda dari A. Notasi determinan $=\operatorname{det}(\mathrm{A})$ dari sebuah matriks bujur sangkar A (Aini dan Utami, 2013:55).

$$
\operatorname{det} . A=|A|=\left|\begin{array}{lllll}
a_{11} & a_{12} & a_{13} & \mathrm{~K} & a_{1 n} \\
a_{21} & a_{22} & a_{23} & \mathrm{~L} & a_{2 n} \\
\mathrm{M} & \mathrm{M} & \mathrm{M} & \mathrm{L} & \mathrm{M} \\
a_{m 2} & a_{m 2} & a_{m 3} & \mathrm{~L} & a_{m n}
\end{array}\right|
$$


$a_{i j}$,dimana $\mathrm{i}=1,2,3, \ldots, \mathrm{m}$ dan $\mathrm{j}=1,2,3, \ldots, \mathrm{n}$, disebut entri-entri dari determinan A yang berukuran $(m \times n)$.

\section{Matriks Leslie}

Salah satu model pertumbuhan penduduk yang paling umum digunakan oleh para ahli demografi adalah model Matriks Leslie, yang dikembangkan pada tahun 1940 oleh Leslie (Montshiwa, 2007). Selanjutnya Corry dan Oktomi (2016) mengatakan bahwa Matriks Leslie merupakan suatu matriks yang digunakan untuk memprediksi jumlah dan laju pertumbuhan suatu populasi.

Model ini menjelaskan pertumbuhan jenis kelamin penduduk perempuan karena penduduk perempuan bereproduksi. Pada suatu penduduk menghitung prediksi jumlah penduduk dengan Matriks Leslie untuk tahun berikutnya dipengaruhi oleh tingkat kesuburan dan tingkat ketahanan hidup penduduk. Didefinisikan $a_{i}$ sebagai tingkat kesuburan penduduk yaitu rata-rata jumlah anak yang lahir dari kelompok umur $i$ saat waktu ke $t$. Didefinisikan $b_{i}$ sebagai tingkat ketahanan hidup penduduk yaitu peluang penduduk yang dapat bertahan hidup dari kelas umur ke $i$ sampai $i+1$ saat waktu ke $t$ (Pratama dkk, 2013).

$$
\begin{aligned}
& a_{i} \geq 0 \text { untuk } i=1,2, \ldots, n \\
& 0<b_{i} \leq 1 \text { untuk } i=1,2, \ldots, n-1
\end{aligned}
$$

Berdasarkan batasan masalah diketahui bahwa paling sedikit satu kelas umur dari $a_{i}=0$, karena jika $a_{i}=0$ maka pada kelas tersebut tidak ada kelahiran yang terjadi. Kelas umur yang memiliki nilai $a_{i}>0$, disebut kelas umur kesuburan. Diketahui $b_{i} \neq 0$, karena jika $b_{i}=0$, maka tidak ada penduduk yang dapat bertahan hidup ke kelas berikutnya.

Pada model penelitian ini penduduk dibagi menjadi kelas-kelas umum dalam durasi waktu yang sama. Dengan batas umur hidup dari penduduk adalah $A$ tahun, dan populasi dibagi menjadi kelas umur, maka masing-masing kelas umur memiliki rentang $A / i$ umur tahun. Sebagai contoh dapat dilihat pada tabel 1 .

TABEL 1. Penentuan Kelas Umur

\begin{tabular}{cc}
\hline Kelas Umur & Rentang Umur \\
\hline 1 & {$\left[0, \frac{A}{i}\right)$} \\
\hline 2 & {$\left[\frac{2 A}{i}, \frac{2 A}{i}\right)$} \\
3 & {$\left[\frac{(i-2) A}{i}, \frac{(i-1) A}{i}\right)$} \\
$i-1$ & {$\left[\frac{(i-1) A}{i}, A\right]$} \\
& \\
\hline
\end{tabular}

Diketahui jumlah populasi penduduk pada masing-masing umur pada saat $t=0$, dan dimisalkan $n_{1}(t)$ adalah jumlah penduduk di kelas umur pertama $n_{2}(t)$ adalah jumlah penduduk 
di kelas umur kedua, dan seterusnya sampai $n_{i}(t)$ adalah jumlah penduduk dikelas umur $i$, maka jumlah keseluruhan penduduk adalah

$$
n(t)=n_{1}(t)+n_{2}(t)+n_{3}(t)+\mathrm{L}+n_{i}(t)
$$

Jumlah penduduk pada masing-masing kelas umur saat $t$ dapat ditulis

$$
n(t)=\left[\begin{array}{c}
n_{1}(t) \\
n_{2}(t) \\
n_{3}(t) \\
\mathrm{M} \\
n_{i}(t)
\end{array}\right]
$$

Vektor $n(t)$ dinamakan vektor distribusi umur awal.

Untuk waktu $(t+1)$ dengan $n_{1}(t+1)$ adalah jumlah populasi di kelas umur pertama, $n_{2}(t+$ 1)adalah jumlah penduduk di kelas umur kedua, dan seterusnya sampai $n_{i}(t+1)$ adalah jumlah penduduk di kelas umur ke $i$, maka jumlah keseluruhan penduduk adalah.

$$
n(t+1)=n_{1}(t+1)+n_{2}(t+1)+n_{3}(t+1)+\ldots+n_{i}(t+1)
$$

Vektor distribusi umur $n$ saat $t+1$ dapat ditulis

$$
n(t+1)=\left[\begin{array}{c}
n_{1}(t+1) \\
n_{2}(t+1) \\
n_{3}(t+1) \\
\mathrm{M} \\
n_{i}(t+1)
\end{array}\right]
$$

Didefenisikan pada waktu $t+1$, penduduk pada kelas umur ke 1 adalah

$$
n_{1}(t+1)=a_{1} n_{1}(t)+a_{2} n_{2}(t)+a_{3} n_{3}(t)+\ldots+a_{i} n_{i}(t)
$$

Jika jumlah penduduk pada saat $t$ untuk setiap kelas umurnya mencapai tahun ke $t+1$, maka untuk kelas umur pertama pada penduduk saat $t+1$ adalah semua jumlah penduduk yang dilahirkan dan berada saat ke $t$.

Didefenisikan jumlah penduduk pada kelas umur ke $i+1$ dengan $i=1,2, . ., n-1$ saat waktu $t+1$ adalah rata-rata jumlah penduduk pada kelas umur ke $i$ pada waktu ke $t$ yang bertahan hidup saat waktu $t+1$. Sehingga dapat ditulis

$$
n_{i+1}(t+1)=b_{i} n_{i}(t), i=1,2, \ldots, i-1
$$

Dapat dibentuk model pertumbuhan penduduk:

$$
\left[\begin{array}{c}
n_{1}(t+1) \\
n_{2}(t+1) \\
n_{3}(t+1) \\
\mathrm{M} \\
n_{i}(t+1)
\end{array}\right]=\left[\begin{array}{ccccc}
a_{1} & a_{2} & \mathrm{~L} & a_{i-1} & a_{i} \\
b_{1} & 0 & \mathrm{~L} & 0 & 0 \\
0 & b_{2} & \mathrm{O} & 0 & 0 \\
\mathrm{M} & \mathrm{M} & \mathrm{O} & \mathrm{M} & \mathrm{M} \\
0 & 0 & 0 & b_{i-1} & 0
\end{array}\right]\left[\begin{array}{c}
n_{1}(t) \\
n_{2}(t) \\
n_{3}(t) \\
\mathrm{M} \\
n_{i}(t)
\end{array}\right]
$$

Atau model pertumbuhan dapat ditulis sebagai berikut:

$$
n(t+1)=\boldsymbol{A} n(t)
$$

dimana:

$n(t+1)$ : vektor penduduk yang berisi prediksi jumlah penduduk pada kelas saat $t+1$.

$\boldsymbol{A} \quad$ : sebuah Matriks Leslie berukuran $n \times n$.

$n(t) \quad$ : vektor populasi yang berisi jumlah penduduk pada kelas umur saat $t$. 
Penduduk pada kelas umur kedua saat $t+1$ adalah penduduk yang berada pada kelas umur pertama saat $t$ yang dapat bertahan hidup hingga saat $t+1$. Penduduk pada kelas umur ketiga saat $t+1$ adalah penduduk yang berada pada kelas umur kedua saat $t$ yang dapat bertahan hidup hingga saat $t+1$. Dan seterusnya hingga penduduk pada kelas umur ke $i$ saat $t+1$.

\section{Nilai Eigen}

Definisi 2.3 (Anton dan Rorres, 2004:384)

Jika A adalah sebuah Matriks $\mathrm{n} \times \mathrm{n}$, maka sebuah vektor taknol $\mathrm{x}$ pada $\mathrm{R}^{\mathrm{n}}$ disebut vektor eigen (eigenvector) dari A jika Ax adalah sebuah kelipatan skalar dari x.

Untuk lebih jelasnya terdapat pada persamaan (2).

$$
A x=\lambda x
$$

Dimana:

$A$ : Matriks $n \times n$

$\lambda$ : nilai eigen (eigen value) dari $A$

$x$ : vektor eigen dari $A$ yang terkait dengan $\lambda$

atau secara ekuivalen terdapat pada persamaan (3),

$$
(\lambda I-A) x=0
$$

Agar $\lambda$ dapat menjadi nilai eigen, harus terdapat satu solusi taknol dari persamaan (3), jika dan hanya jika memenuhi persamaan (4)

$$
\operatorname{det}(\lambda I-A)=0
$$

\section{Nilai Eigen Matriks Leslie}

Diketahui persamaan (2) hanya digunakan untuk memprediksi jumlah pertumbuhan penduduk sedangkan untuk memprediksi laju pertumbuhan penduduk digunakan nilai eigen dari Matriks Leslie. Nilai eigen yang dominan dapat menunjukkan laju pertumbuhan penduduk cenderung naik, tetap atau menurun.

Teorema 2.1 (Pratama dkk, 2013)

Sebuah Matriks memiliki sebuah nilai eigen positif yang tunggal $\lambda_{1}$, nilai eigen ini memiliki multiplisitas satu dan sebuah vektor eigen $\mathbf{x}_{\mathbf{1}}$ yang seluruh entri-entrinya adalah positif.

Teorema 2.2 (Pratama dkk, 2013)

Jika $\lambda_{1}$ adalah suatu nilai eigen positif yang tunggal dari sebuah Matriks Leslie dan $\lambda_{\mathrm{k}}$ adalah sebarang nilai eigen bilangan real atau bilangan kompleks dari Matriks Leslie tersebut, maka $\mid \lambda_{\mathrm{k}}$ $\mid \leq \lambda_{1}$.

Definisi 2.4 (Pratama dkk, 2013)

Diberikan $\lambda_{1}, \lambda_{2}, \ldots, \lambda_{\mathrm{n}}$ merupakan nilai eigen dari matriks A berukuran $\mathrm{n} \times \mathrm{n}, \lambda_{1}$ dikatakan nilai eigen dominan dari A jika:

$\left|\lambda_{1}\right|>\left|\lambda_{i}\right|$ dengan $i=1,2, \ldots, n$.

Dengan melakukan pendiagonalisasian matriks diperoleh persamaan (5)

$$
n(t+p)=\lambda_{1} n(t+(p-1))
$$


Dari persamaan (5) diperoleh bahwa, jika untuk sebarang $p$ yang menyatakan tahun berikutnya dalam populasi dan diketahui $\lambda_{1}=1$ adalah nilai eigen yang dominan dari Matriks Leslie, maka dapat diambil kesimpulan bahwa vektor distribusi umur berikutnya selalu sama dengan vektor umur sebelumnya. Sehingga berakibat:

1. Jika diketahui $\lambda_{1}<1$, maka pertumbuhan jumlah populasi akan cenderung menurun.

2. Jika diketahui $\lambda_{1}=1$, maka pertumbuhan jumlah populasi akan cenderung tetap.

3. Jika diketahui $\lambda_{1}>1$, maka pertumbuhan jumlah populasi akan cenderung meningkat.

\section{METODE PENELITIAN}

Penelitian ini termasuk dalam kategori penelitian terapan (Applied Research) dimana model Matriks Leslie diterapkan dalam bidang demografi yaitu untuk memprediksi jumlah dan laju pertumbuhan penduduk di Kota Makassar. Berdasarkan data jumlah penduduk tahun 2014 dan 2015 yang diperoleh dari Badan Pusat Statistika, kemudian dimasukkan ke dalam model Matriks Leslie untuk dilihat apakah jumlah dan laju pertumbuhan penduduk meningkat, tetap atau menurun.

Untuk mencapai tujuan penelitian yang tertera pada pendahuluan, maka prosedur pelaksanaan penelitian yang ditempuh adalah sebagai berikut:

1. Identifikasi masalah yang terkait dengan pertumbuhan penduduk dan laju pertumbuhannya, kemudian merumuskan masalah serta merumuskan tujuan dan manfaat penelitian yang diperoleh dalam penelitian ini.

2. Mencari referensi yang terkait dengan objek penelitian.

3. Pengumpulan data. Dalam tahap ini data yang dikumpulkan adalah data sekunder yang diperoleh dari Badan Pusat Statistika (BPS) kota Makassar yaitu data jumlah penduduk jenis kelamin perempuan tahun 2014 dan 2015 di Kota Makassar.

4. Pengolahan data menjadi data tingkat kesuburan penduduk dan data tingkat ketahanan hidup penduduk

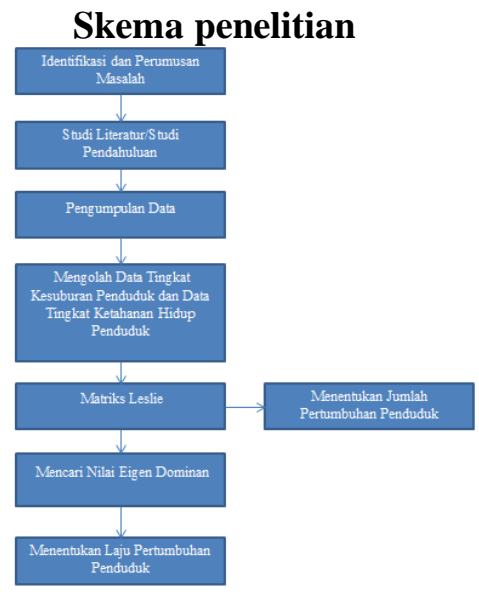

GAMBAR 1. Langkah-Langkah Prosedur Penelitian

\section{HASIL DAN PEMBAHASAN}

Matriks Leslie memiliki karakteristik dalam pembentukkannya, yang membedakan dengan bentuk Matriks pada umumnya. Karakteristik Matriks Leslie pertama terletak pada elemen Matriks Leslie yang hanya ditentukan dengan dua fakor yakni, tingkat kesuburan dan tingkat ketahanan hidup. Kedua, aturan letak elemen Matriks Leslie, pada baris pertama elemen Matriks 
Leslie berisikan entri-entri dari tingkat kesuburan, dan elemen subdiagonalnya berisikan entrientri dari tingkat ketahanan hidup. Sedangkan elemen yang lain bernilai nol.

Untuk mengetahui prediksi jumlah pertumbuhan penduduk hingga $p$ tahun berikutnya dilakukan beberapa pengembangan.

Diperoleh:

$$
\begin{aligned}
n(t+1) & =\boldsymbol{A} n(t) \\
n(t+2) & =\boldsymbol{A} n(t+1)=\boldsymbol{A} \boldsymbol{A} n(t)=\boldsymbol{A}^{2} n(t) \\
n(t+3) & =\boldsymbol{A} n(t+2)=\boldsymbol{A} \boldsymbol{A}^{2} n(t)=\boldsymbol{A}^{3} n(t) \\
n(t+4) & =\boldsymbol{A} n(t+3)=\boldsymbol{A} \boldsymbol{A}^{3} n(t)=\boldsymbol{A}^{4} n(t) \\
n(t+5) & =\boldsymbol{A} n(t+4)=\boldsymbol{A} \boldsymbol{A}^{4} n(t)=\boldsymbol{A}^{5} n(t) \\
& \mathbf{M} \\
n(t+p) & =\boldsymbol{A} n(t+(p-1))=\boldsymbol{A} \boldsymbol{A}^{p-1} n(t)=\boldsymbol{A}^{p} n(t)
\end{aligned}
$$

Sehingga untuk $p$ tahun berikutnya, model pertumbuhan penduduk yaitu sebagaimana pada persamaan (6).

$$
n(t+p)=\boldsymbol{A}^{p} n(t)
$$

\begin{tabular}{|c|c|c|}
\hline Kelas Umur & $\begin{array}{c}\text { Jumlah Perempuan Tahun } \\
2014\end{array}$ & $\begin{array}{c}\text { Jumlah Perempuan Tahun } \\
2015\end{array}$ \\
\hline $0-4$ & 67.081 & 67.474 \\
\hline $5-9$ & 59.808 & 60.361 \\
\hline $10-14$ & 56.835 & 56.767 \\
\hline $15-19$ & 80.347 & 80.923 \\
\hline $20-24$ & 92.592 & 93.787 \\
\hline $25-29$ & 66.200 & 66.916 \\
\hline $30-34$ & 58.531 & 58.574 \\
\hline $35-39$ & 51.893 & 52.511 \\
\hline $40-44$ & 49.579 & 50.370 \\
\hline $45-49$ & 40.927 & 42.243 \\
\hline $50-54$ & 29.496 & 30.741 \\
\hline $55-59$ & 23.202 & 24.188 \\
\hline $60-64$ & 16.303 & 16.964 \\
\hline $65+$ & 29.634 & 30.535 \\
\hline Total & 722.428 & 732.354 \\
\hline
\end{tabular}

Dimana:

$n(t+p)$ : vektor penduduk yang berisi prediksi jumlah penduduk pada kelas saat $t+p$.

$\boldsymbol{A} \quad$ : sebuah Matriks Leslie berukuran $n \times n$.

$n(\mathrm{t}) \quad$ : vektor populasi yang beridi jumlah penduduk pada kelas umur saat $t$.

Untuk pengaplikasian Matriks Leslie diberikan data jumlah penduduk perempuan pada tahun 2014 dan 2015 yang dikelompokkan berdasarkan umurnya, terlihat pada tabel 2.

TABEL 2. Data Jumlah Perempuan Tahun 2014 dan 2015

Model Matriks Leslie dapat digunakan untuk menghitung julah penduduk perempuan pada 2 tahun berikutnya. Dengan menggunakan Matriks Leslie, berdasarkan tabel 4. Jumlah penduduk perempuan dibagi atas beberapa interval kelas umur, dengan interval umur kesuburan perempuan yaitu 15-49 tahun. Untuk menghitung jumlah penduduk perempuan dengan Matriks Leslie diperlukan faktor tingkat kesuburan $a_{i}$ dan tingkat ketahanan hidup $b_{i}$. 
Berdasarkan tabel 2 maka penduduk perempuan dapat dikelompokkan berdasarkan kelas umurnya seperti pada tabel 3 .

TABEL 3. Pengelompokan Penduduk Perempuan Tahun 2014 dan 2015 Berdasarkan Estimasi ASFR dan Kelas Umur

\begin{tabular}{cccc}
\hline Kelas Umur & $\begin{array}{c}\text { Jumlah } \\
\text { Perempuan } \\
\text { Tahun 2014 }\end{array}$ & $\begin{array}{c}\text { Jumlah Anak yang } \\
\text { Lahir Tahun 2014-2015 }\end{array}$ & $\begin{array}{c}\text { Jumlah Perempuan } \\
\text { Tahun 2015 }\end{array}$ \\
\hline $0-4$ & 67.081 & 0 & 67.474 \\
$5-9$ & 59.808 & 0 & 60.361 \\
$10-14$ & 56.835 & 0 & 56.767 \\
$15-19$ & 80.347 & 3.758 & 80.923 \\
$20-24$ & 92.592 & 16.811 & 93.787 \\
$25-29$ & 66.200 & 18.252 & 66.916 \\
$30-34$ & 58.531 & 15.917 & 58.574 \\
$35-39$ & 51.893 & 9.375 & 52.511 \\
$40-44$ & 49.579 & 3.379 & 50.370 \\
$45-49$ & 40.927 & 0 & 42.243 \\
$50-54$ & 29.496 & 0 & 30.741 \\
$55-59$ & 23.202 & 0 & 24.188 \\
$60-64$ & 16.303 & 0 & 16.964 \\
$65+$ & 29.634 & 0 & 30.535 \\
\hline Total & 722.428 & 67.474 & 732.354 \\
\hline Sumber $:$ Badan Pusat Statistika dan berdasar data ASFR
\end{tabular}

Berikut tabel 4 yang merupakan data yang digunakan untuk menghitung pertumbuhan jumlah penduduk perempuan di Kota Makassar pada Tahun 2017.

TABEL 4. Data Tingkat Kesuburan dan Ketahanan Hidup Penduduk Perempuan Tahun 2014 dan 2015

\begin{tabular}{lcc}
\hline Kelas Umur & $\boldsymbol{a}_{\boldsymbol{i}}$ & $\boldsymbol{b}_{\boldsymbol{i}}$ \\
\hline $0-4$ & 0 & 0.8998 \\
$5-9$ & 0 & 0.9492 \\
$10-14$ & 0 & 1.4238 \\
$15-19$ & 0.0468 & 1.1673 \\
$20-24$ & 0.1816 & 0.7227 \\
$25-29$ & 0.2757 & 0.8848 \\
$30-34$ & 0.2719 & 0.8971 \\
$35-39$ & 0.1803 & 0.9707 \\
$40-44$ & 0.0682 & 0.8520 \\
$45-49$ & 0 & 0.7511 \\
$50-54$ & 0 & 0.8200 \\
$55-59$ & 0 & 0.7311 \\
$60-64$ & 0 & 1.8730 \\
\hline
\end{tabular}


$65+$

Berdasarkan tabel 4 diperoleh Matriks Leslie sebagai berikut:

$$
\boldsymbol{A}=\left[\begin{array}{llllllllllllll}
0 & 0 & 0 & 0.0468 & 0.1816 & 0.2757 & 0.2719 & 0.1803 & 0.0682 & 0 & 0 & 0 & 0 & 0 \\
0.8998 & 0 & 0 & 0 & 0 & 0 & 0 & 0 & 0 & 0 & 0 & 0 & 0 & 0 \\
0 & 0.9492 & 0 & 0 & 0 & 0 & 0 & 0 & 0 & 0 & 0 & 0 & 0 & 0 \\
0 & 0 & 1.4238 & 0 & 0 & 0 & 0 & 0 & 0 & 0 & 0 & 0 & 0 & 0 \\
0 & 0 & 0 & 1.1673 & 0 & 0 & 0 & 0 & 0 & 0 & 0 & 0 & 0 & 0 \\
0 & 0 & 0 & 0 & 0.7227 & 0 & 0 & 0 & 0 & 0 & 0 & 0 & 0 & 0 \\
0 & 0 & 0 & 0 & 0 & 0.8848 & 0 & 0 & 0 & 0 & 0 & 0 & 0 & 0 \\
0 & 0 & 0 & 0 & 0 & 0 & 0.8971 & 0 & 0 & 0 & 0 & 0 & 0 & 0 \\
0 & 0 & 0 & 0 & 0 & 0 & 0 & 0.9707 & 0 & 0 & 0 & 0 & 0 & 0 \\
0 & 0 & 0 & 0 & 0 & 0 & 0 & 0 & 0.8520 & 0 & 0 & 0 & 0 & 0 \\
0 & 0 & 0 & 0 & 0 & 0 & 0 & 0 & 0 & 0.7511 & 0 & 0 & 0 & 0 \\
0 & 0 & 0 & 0 & 0 & 0 & 0 & 0 & 0 & 0 & 0.8200 & 0 & 0 & 0 \\
0 & 0 & 0 & 0 & 0 & 0 & 0 & 0 & 0 & 0 & 0 & 0.7311 & 0 & 0 \\
0 & 0 & 0 & 0 & 0 & 0 & 0 & 0 & 0 & 0 & 0 & 0 & 1.8730 & 0
\end{array}\right]
$$

Diketahui $p=2$ yang berarti dua tahun mendatang dan $t=1$ dimana $\mathrm{n}(1)$ adalah jumlah perempuan tahun 2015 sebagai jumlah populasi awal.

Dengan menggunakan persamaan (4.1) diperoleh :

$$
\begin{aligned}
& n(t+p)=\boldsymbol{A}^{p} n(t) \\
& n(1+2)=A^{2} n(1) \\
& n(3)=A^{2} n(1) \\
& n(3)=\left[\begin{array}{llllllllllllll}
0 & 0 & 0 & 0.0468 & 0.1816 & 0.2757 & 0.2719 & 0.1803 & 0.0682 & 0 & 0 & 0 & 0 & 0 \\
0.8998 & 0 & 0 & 0 & 0 & 0 & 0 & 0 & 0 & 0 & 0 & 0 & 0 & 0 \\
0 & 0.9492 & 0 & 0 & 0 & 0 & 0 & 0 & 0 & 0 & 0 & 0 & 0 & 0 \\
0 & 0 & 1.4238 & 0 & 0 & 0 & 0 & 0 & 0 & 0 & 0 & 0 & 0 & 0 \\
0 & 0 & 0 & 1.1673 & 0 & 0 & 0 & 0 & 0 & 0 & 0 & 0 & 0 & 0 \\
0 & 0 & 0 & 0 & 0.7227 & 0 & 0 & 0 & 0 & 0 & 0 & 0 & 0 & 0 \\
0 & 0 & 0 & 0 & 0 & 0.8848 & 0 & 0 & 0 & 0 & 0 & 0 & 0 & 0 \\
0 & 0 & 0 & 0 & 0 & 0 & 0.8971 & 0 & 0 & 0 & 0 & 0 & 0 & 0 \\
0 & 0 & 0 & 0 & 0 & 0 & 0 & 0.9707 & 0 & 0 & 0 & 0 & 0 & 0 \\
0 & 0 & 0 & 0 & 0 & 0 & 0 & 0 & 0.8520 & 0 & 0 & 0 & 0 & 0 \\
0 & 0 & 0 & 0 & 0 & 0 & 0 & 0 & 0 & 0.7511 & 0 & 0 & 0 & 0 \\
0 & 0 & 0 & 0 & 0 & 0 & 0 & 0 & 0 & 0 & 0.8200 & 0 & 0 & 0 \\
0 & 0 & 0 & 0 & 0 & 0 & 0 & 0 & 0 & 0 & 0 & 0.7311 & 0 & 0 \\
0 & 0 & 0 & 0 & 0 & 0 & 0 & 0 & 0 & 0 & 0 & 0 & 1.8730 & 0
\end{array}\right]^{2}\left[\begin{array}{l}
67.474 \\
60.361 \\
56.767 \\
80.923 \\
93.787 \\
66.916 \\
58.574 \\
52.511 \\
50.370 \\
42.243 \\
30.741 \\
24.188 \\
16.964 \\
30.535
\end{array}\right]
\end{aligned}
$$




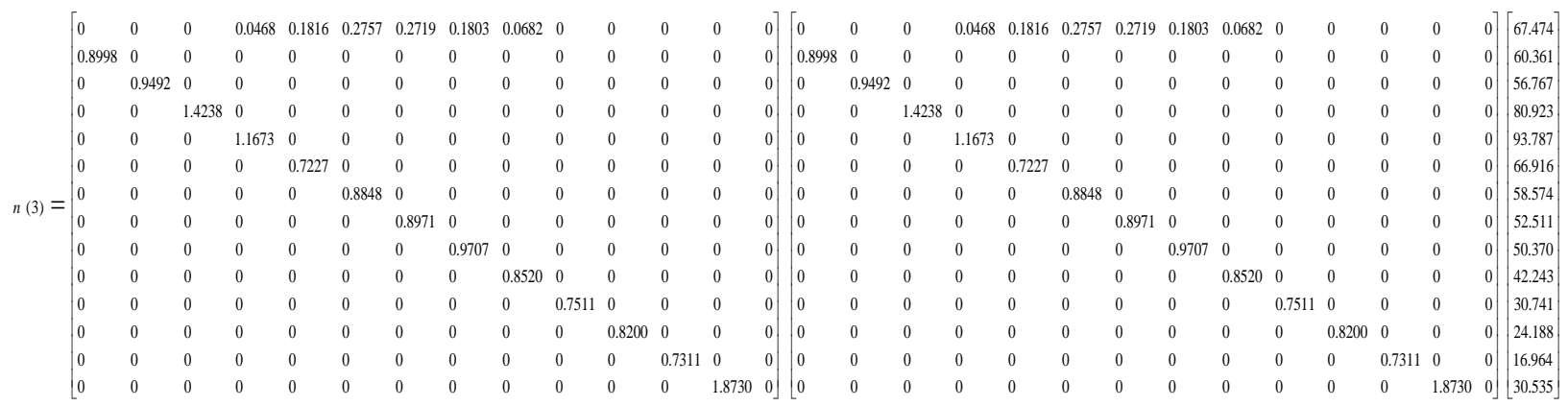

\begin{tabular}{|c|c|c|c|c|c|c|c|c|c|c|c|c|c|c|c|}
\hline \multirow{14}{*}{$n(3)=$} & 0 & 0 & 0.0666 & 0.2120 & 0.1992 & 0.2406 & 0.1617 & 0.0662 & 0 & 0 & 0 & 0 & 0 & 0 & 67.474 \\
\hline & 0 & 0 & 0 & 0.0421 & 0.1634 & 0.2481 & 0.2447 & 0.1622 & 0.0614 & 0 & 0 & 0 & 0 & 0 & 60.361 \\
\hline & 0.8541 & 0 & 0 & 0 & 0 & 0 & 0 & 0 & 0 & 0 & 0 & 0 & 0 & 0 & 56.767 \\
\hline & 0 & 1.3515 & 0 & 0 & 0 & 0 & 0 & 0 & 0 & 0 & 0 & 0 & 0 & 0 & 80.923 \\
\hline & 0 & 0 & 1.662 & 0 & 0 & 0 & 0 & 0 & 0 & 0 & 0 & 0 & 0 & 0 & 93.787 \\
\hline & 0 & 0 & 0 & 0.8436 & 0 & 0 & 0 & 0 & 0 & 0 & 0 & 0 & 0 & 0 & 66.916 \\
\hline & 0 & 0 & 0 & 0 & 0.6394 & 0 & 0 & 0 & 0 & 0 & 0 & 0 & 0 & 0 & 58.574 \\
\hline & 0 & 0 & 0 & 0 & 0 & 0.7938 & 0 & 0 & 0 & 0 & 0 & 0 & 0 & 0 & 52.511 \\
\hline & 0 & 0 & 0 & 0 & 0 & 0 & 0.8708 & 0 & 0 & 0 & 0 & 0 & 0 & 0 & 50.370 \\
\hline & 0 & 0 & 0 & 0 & 0 & 0 & 0 & 0.8270 & 0 & 0 & 0 & 0 & 0 & 0 & 42.243 \\
\hline & 0 & 0 & 0 & 0 & 0 & 0 & 0 & 0 & 0.6399 & 0 & 0 & 0 & 0 & 0 & 30.741 \\
\hline & 0 & 0 & 0 & 0 & 0 & 0 & 0 & 0 & 0 & 0.6159 & 0 & 0 & 0 & 0 & 24.188 \\
\hline & 0 & 0 & 0 & 0 & 0 & 0 & 0 & 0 & 0 & 0 & 0.5995 & 0 & 0 & 0 & 16.964 \\
\hline & 0 & 0 & 0 & 0 & 0 & 0 & 0 & 0 & 0 & 0 & 0 & 1.3694 & 0 & 0 & 30.535 \\
\hline
\end{tabular}

$n(3)=\left[\begin{array}{l}68.673 \\ 61.274 \\ 57.629 \\ 81.576 \\ 94.347 \\ 68.267 \\ 59.972 \\ 53.115 \\ 51.007 \\ 43.429 \\ 32.234 \\ 26.018 \\ 18.429 \\ 33.122\end{array}\right]$




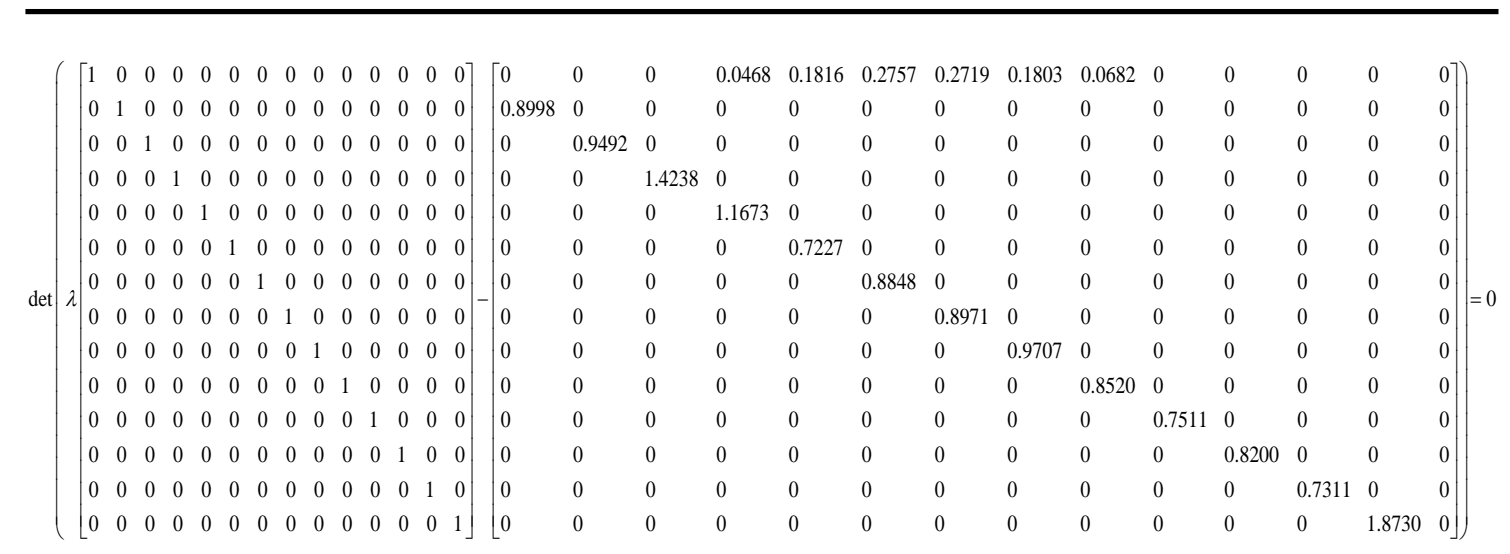

Jadi prediksi total dari jumlah penduduk perempuan pada tahun 2017 di Kota Makassar adalah $68.673+61.274+57.629+81.576+94.347+68.267+59.972+53.115+51.007+43.429+$ $32.234+26.018+18.429+33.122=749.090$ jiwa. Hal ini menandakan peningkatan sebanyak 16.738 jiwa dari total jumlah penduduk perempuan pada tahun 2015 yang berjumlah 732.354 jiwa.

Selanjutnya, diprediksi laju pertumbuhan penduduk perempuan dengan menggunakan nilai eigen $(\lambda)$ dari Matriks Leslie. Untuk menghitung nilai eigen dari Matriks Leslie digunakan persamaan ( $\operatorname{det}(\lambda I-A)=0)$.

Dengan menggunakan ekspansi kofaktor diperoleh persamaan karakteristiknya yakni:

$$
\lambda^{14}-0.0569 \lambda^{10}-0.2578 \lambda^{9}-0.2828 \lambda^{8}-0.2468 \lambda^{7}-0.1468 \lambda^{6}-0.0539 \lambda^{5}=0
$$

Dari persamaan karakteristiknya kemudian diselesaikan dengan menggunakan aplikasi MATLAB untuk memperoleh nilai-nilai eigennya.

Nilai eigen yang diperoleh adalah $\lambda_{1}=1.01, \lambda_{2}=0.50+0.72 \mathrm{i}, \lambda_{3}=0.50-0.72 \mathrm{i}, \lambda_{4}=0.01+0.66 \mathrm{i}, \lambda_{5}=$ $0.01-0.66 \mathrm{i}, \lambda_{6}=-0.41+0.50 \mathrm{i}, \lambda_{7}=-0.41-0.50 \mathrm{i}, \lambda_{8}=-0.58+0.23 \mathrm{i}, \lambda_{9}=-0.58-0.23 \mathrm{i}$. Berdasarkan Teorema 2.2 dan Definisi 2.4 nilai eigen yang dominan adalah $\lambda_{1}=1.01$, karena nilai eigen dominan lebih besar dari satu, maka nilai ini menunjukkan bahwa laju pertumbuhan penduduk Kota Makassar cenderung naik.

\section{KESIMPULAN}

Berdasarkan hasil dan pembahasan maka diperoleh kesimpulan sebagai berikut :

1. Matriks Leslie dengan karakteristiknya telah mampu memberikan solusi pemecahan masalah, dalam penelitian ini digunakan untuk memprediksi jumlah dan laju pertumbuhan penduduk di Kota Makassar pada tahun 2017. Perhitungan pertumbuhan penduduk dengan menggunakan Matriks Leslie dengan persamaan $n(t+p)=A^{p} n(t)$ dapat menghitung hingga $p$ tahun berikutnya.

2. Hasil pengaplikasian Matriks Leslie menunjukkan bahwa jumlah penduduk Kota Makassar pada tahun 2016 dan 2017 dalam skala satu tahun sebanyak 741.207 jiwa dan 749.089 jiwa. Prediksi jumlah penduduk perempuan tahun 2017 dalam skala dua tahun sebanyak 749.090 jiwa hal ini menunjukan bahwa laju pertumbuhan penduduk perempuan Kota Makassar pada tahun 2017 dalam perhitungan skala satu tahun maupun dua tahun cenderung meningkat. 


\section{DAFTAR PUSTAKA}

Anton, H., dan Rorres, A. (2014). Aljabar Liniear Elementer Versi Aplikasi Edisi Kedelapan. Jakarta: Erlangga

Daniel. (2014). BKKBN Paparkan Laju Pertumbuhan Penduduk Makassar. http://www.antarasulsel.com/berita/55131/bkkbn-paparkan-laju-pertumbuhanpenduduk-makassar. diakses pada tanggal 15 Maret 2017.

Pratama, Y., Pribahandono, B., dan Kusumasturi, N. (2013). Aplikasi Matriks Leslie Untuk Memprediksi Jumlah dan Laju Pertumbuhan Suatu Populasi. Buletin Ilmiah Math. Stat. Dan terapannya, 2(3). 163-172.

Yuliani, S., Rahayu, B., V., \& Mashuri. (2012). Penerapan Diagonalisasi Matriks dan Matriks Leslie Dalam Memproyeksikan Jumlah Populasi Perempuan. UNNES Journal of Mathematics 1 (1). 